To the Lee. A Cadence

Author(s): A. C.

Source: All Ireland Review, Vol. 2, No. 43 (Dec. 28, 1901), p. 363

Published by: All Ireland Review

Stable URL: http://www.jstor.org/stable/20545734

Accessed: 18-01-2016 00:51 UTC

Your use of the JSTOR archive indicates your acceptance of the Terms \& Conditions of Use, available at http://www.jstor.org/page/ info/about/policies/terms.jsp

JSTOR is a not-for-profit service that helps scholars, researchers, and students discover, use, and build upon a wide range of content in a trusted digital archive. We use information technology and tools to increase productivity and facilitate new forms of scholarship. For more information about JSTOR, please contact support@ jstor.org. 
sum out of it to find out how much you waste in smoke every year, I multiply the number of weeks in the yenr by the sixpence which you spend ench week on tobacco. It comes to 312 pence, which, reduced to shillings and pounds, is exictly 11 Gs.

(3) There now; 't is you're the fine cholitrd, Mister Jamesie.

(2) Why, then, now.

(1) Now, Curly, what's the price of a nice young cow?

(2) Well, you'd get a rale nice wan in calf, for a matter o' twelve pounds, or thereabout.

(At this point the wise old man detects the drift of the ingenuous little boy, his eyes twinkles more merrily, and his mouth assumes a very humorous expression; 4,5 , and 6 begin to attend and look intelligent).

(1) Now, Cum y, if instead of wasting your noney on smoke you were to put into a safe place every week that sixpenee that you are now wasting to the injury of rour henlth too, at the end of ten years you would have $\$ 13$ saved enough to buy the cow, and a pound over.

And then, Gurly, the cow would have a calf, and besides all the milk, you wonld have in another year a second cow, and the two would have calves, and in a short time you wonls be the owner of a fine herd and be a rich man Why don't you do it?

No. 3 langhs Ioud; No. 5 walles ont in the manner described; No. 4 rushes throngh the legs of a chair and scrapes No. 6 off his back.

2) Well Master Jamesie. Let me tell you a story. There was a bye (boy) here wanst who began to raison with himself in that way, and he bought a box with a lock on it, and he stopped smoking, and as sure as Saturday night cem around, he'd put a bright sixpence into the box; so he would, aviceo?

And he was in that penitential condition for many a melancholious year. and at long last he bought the cow and drav low home from the fair in glory, and he put her out on the hill and sted watehing her till black night; and then henes with him ard to bed.

But he cond n't sloep be raison of thinking of his baatifnl baste on the lill. 50 , with the first light he ups and away with hirm to be looking at her, and it, was long before he found her, and when he did he was n't aver well plazed the sight ; for she was clifted (killed by falling over a elift). (vilence broken only by the crackling of tho claws of No, 4.)

1st critic. This is ridiculous. Irish literury drama, indeed! Why there's no action.

Anthor. Well there is some, and 4,5 , and 6 do nothing but act. Then according to the greatest dramatist of the age a first-rate drama should have no action. Then what is literature? You can't define it. I say this is literature, and this a literary drama. The play is Irish, is literary, and is a drama.

2nd critic And the cuckoo? Absurd! nonsenical!!

Author. Your minds are too carpino and prosaio to comprehend. Otherwise $I$ would explain the profound significance of the bird. A word nevertheless. That cuckoo was no cuckoo.

Both critics. Do you think us fools?

\section{TO THE LEE}

\section{A Cadence.}

O Lee, still beautiful winding Lee, my own Lee.

O dear companion, day after day receiving may thoughts, imparting yours.

Never obtrusive and never sullen; face always pleasing to see, voice always sweet to hear.

O Lee, my own Isea, still beautiful winding river.

was at your birth-place, O Lee; saw you escaping with difficulty through weeds and long grass from your gloomy mother-

Gougane-Barra-vast, sombre, desolate, the still lake and melancholy hills, the weird little island-

The holy well there, surrounded by rags and white stones, the ruined Abbey and tall gaunt ash-trees.

t was a prison, my Lee, and you escaped, stealthily, through the reeds and long grasses,

And came shouting and laughing down the hills to Inchigeela,

Clad in white, leaping down the rocks with the joy of new freedom, my Lee.

()h! I am enamoured of you, my river; my heart is hot with love to you, my own sweet stream.

You are precious to me, my beautiful, the touch of you thrills me and the sound of your voice.

have seen the Blackwater deep and grand, Lismore Castle rising high above, and the trees along the banks.

And the princely Shannon swelling proudly below Limerick,

and the Liffey I know, and the Suir and the Barrow, and the Royal Boyne.

But, oh, I return always to you, my Lee, aud with ever greater affection Return always to you, my Lee; still, beautiful, winding river.

h, that I could journey the whole way with you, my river, from your birthplace to the sea.

Oh, to be a leaf, blown from the gaunt ash trees, stealing my way through the reeds and long grasses -

Laughing, shouting with you over the rocks, dancing down the hills to Inchigeela.

Borne eastward with you, past $\mathrm{Ma}$ croom-always the touch of your tool, kind hand

And through Aghinagh and Magourney and the woods of Inniscarragh.

Past the Powder Mills of Ballincollig and the steep cliff of Carrigrohane;

And through Cork City, the southern capital, and onward between beautifu highlands to the sea -

Your cool, sweet water, around me.

Here by Roove's bridge you are no longer the bright girl, drest in white, whom I beheld dancing down the hills to Inchigela.

alm and deep are you now, my mother, with large, fond, motherly face, moving downwards to the sea.

Innumerable are your children, my mother, but not one of them loves you like me

My soul was cradled in this, your valley, your foot was upon the rocker. As child, clutching his mother's dress, looks out upon the stranger, so I gather strength to meet the world's face, here by your banks, my native stream.
Oh, you are dear, dear to me, my beau. tiful, often in the rush of crowds, often alone in Dublin or Londonvast, melancholy London.

Serene and beautiful, you flow through me, cooling the hot heart, soothing the unquiet mind-

The tree-boughs stooping to touch you - the cattle standing in your stream. or the sound of your voice as heard at dead of night, southward, in the rapids by Roove's Bridge, sounding all through the night, sound like mother's hushaby to soothe a crying child.

urely they are fools who say that man is the crown of things;

That he absorbs all, and is the flower of all, and rules the world by a right divine.

urse me with a heavy curse, $O \mathrm{my}$ mother, if I ever liken myself to you in anywise-

but a fleck of foam upon your beast - a blade of grass growing upon your marge, watered by your love.

vast and venerable divine, compassionate stream,

Envious and coarse 1 have come to you tyrannical and selfish, moping and cowardly, I have sought your beautiful presence, and have not been refused.

Only your face was sadder, and fonder your fond kiss, my mother.

The oaths I have heard upon your banks inhere not in you, nor have those that bathed in you, left any stain.

You learned no cruelty from the long savage cry of the otter hound, nor from the delight of the fisherman gaffing his prey.

The wealthy have not made you exclusive, nor the down-spirited a slave, and you have not learned contempt from the contemptuous.

$O$ passionate and silent, $O$ eternal and unalterable, running through the centuries never still.

That same song I hear now sounding before Norman or Celt set foot upon this island.

Voice that will sound till the world's girth is loosed, and Chaos returns to claim his own again.

Small share is ours of your silence, of your long, life-diffusing flow

$O$ still with the stillness of intense life, of unfathomable love.

eautiful with ever-changing moods and phases, majestic and musical stream. Rythmic existence from source to sea -the death-like vast sea that receives you at last in his briny arms.

Oh ! it is not meagre humanity that

fills me with the deepest longings.

$t$ is not the strong men of history or of fiction, or the beautiful, or the tender and compassionate.

It is you, my mother stream, and the other voiceless divinities around us

Unapproachably beautiful, beside us yet far away.

Ob! well might men worship you, build high altars, and exact tithes in your service.

Let me love you only, 0 my mother, and I am satisfied.

Let me lie down here beside you, and feel your sweet touch as you glid ove my hands, beautiful river. A. C

Dear A.C.-I don't think much of your "cadence," which, too, is an evident imitation of Wait Whitman. But, in praising one of our noble Irish rivers, you have approached me on my weak side.-ED.-A.I.R. 